Portland State University

PDXScholar

\title{
A Family-Friendly Study Room for Student-Parents and Their Children at Portland State University Library
}

Joan Petit

Portland State University, jpetit@pdx.edu

Follow this and additional works at: https://pdxscholar.library.pdx.edu/ulib_fac

Part of the Library and Information Science Commons

Let us know how access to this document benefits you.

\section{Citation Details}

Joan Petit. "A Family-Friendly Study Room for Student-Parents and Their Children at Portland State University Library" OLA Quarterly 20.1 (2014): 36-39.

This Article is brought to you for free and open access. It has been accepted for inclusion in Library Faculty Publications and Presentations by an authorized administrator of PDXScholar. Please contact us if we can make this document more accessible: pdxscholar@pdx.edu. 


\section{A Family-Friendly Study Room \\ for Student-Parents and Their Children at Portland State University Library}

\section{by Joan Petit}

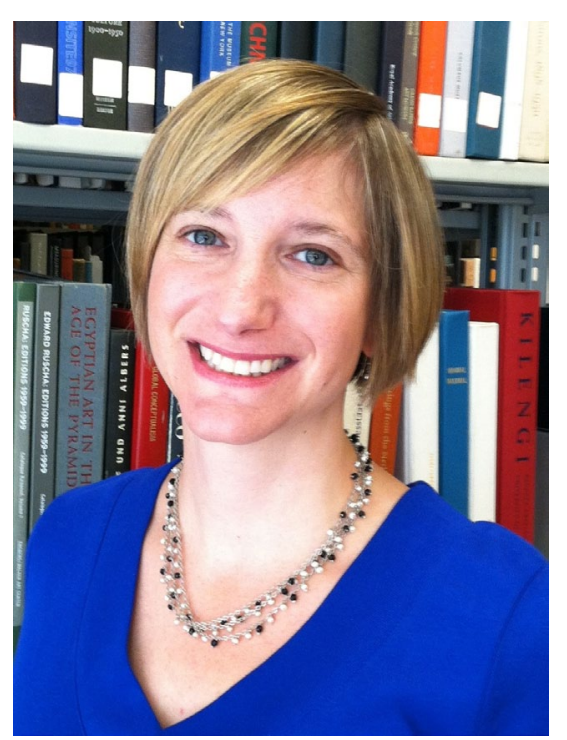

Joan Petit serves as Assistant Professor and Librarian for History,

Black Studies, and Judaic Studies at Portland State University. She holds a BA in English and Women's Studies and an MSLS from the University of North Carolina at Chapel Hill, as well as an MA in English from Western Carolina University. Before moving to Portland in 2009, Joan worked as an instruction and reference librarian at Duke University and the American University in Cairo, Egypt. Her research interests include academic libraries' use of social media as well as technology use by students in libraries. You can reach her at: jpetit@pdx.edu.
Portland State University, an urban university located in downtown Portland, serves a large number of non-traditional students, many of whom have taken long breaks in their post-secondary education or who have transferred to PSU after starting at a community college or other four-year institution. Nationally, most undergraduates are ages 18-24. In Fall of 2012, the most recent term for which statistics are available, PSU enrolled 28,731 students, 23,170 of whom were undergraduates and had an average age of 26.6 years. At many colleges, the freshman class is the largest; at PSU, in Fall 2012, the largest class was the senior class, comprising 34 percent of the student body while freshman numbered only 2,250 , just under 10 percent of the student body. The average junior was 26.3 years old, while the average senior was 28.3 (Portland State University, 2002).

With so many older students, it is no surprise that our student body includes a large number of students with dependent children. While we lack current and precise data, a 2009 campus child care survey suggested that 21.5 percent of PSU students were also parents, and "(o)f the student parents at PSU, approximately 75 percent are women and 54 percent of these women are single parents" (Balzer et al, 2011).

In 2010, PSU commissioned the Presidential Task Force on Child Development and Family Support. According to their 2011 report, "It was apparent from the interviews with parents and data collected, that the need for more family-focused and family-friendly spaces and places on campus in a variety of locations is pressing. [This includes] space for children to play quietly while their parents study or work ..." (Balzer et al, 2011).

At the same time, with campus awareness increasing about the needs of student-parents, thenAssistant University Librarian for Public Services Tom Raffensperger contacted the Helen Gordon 


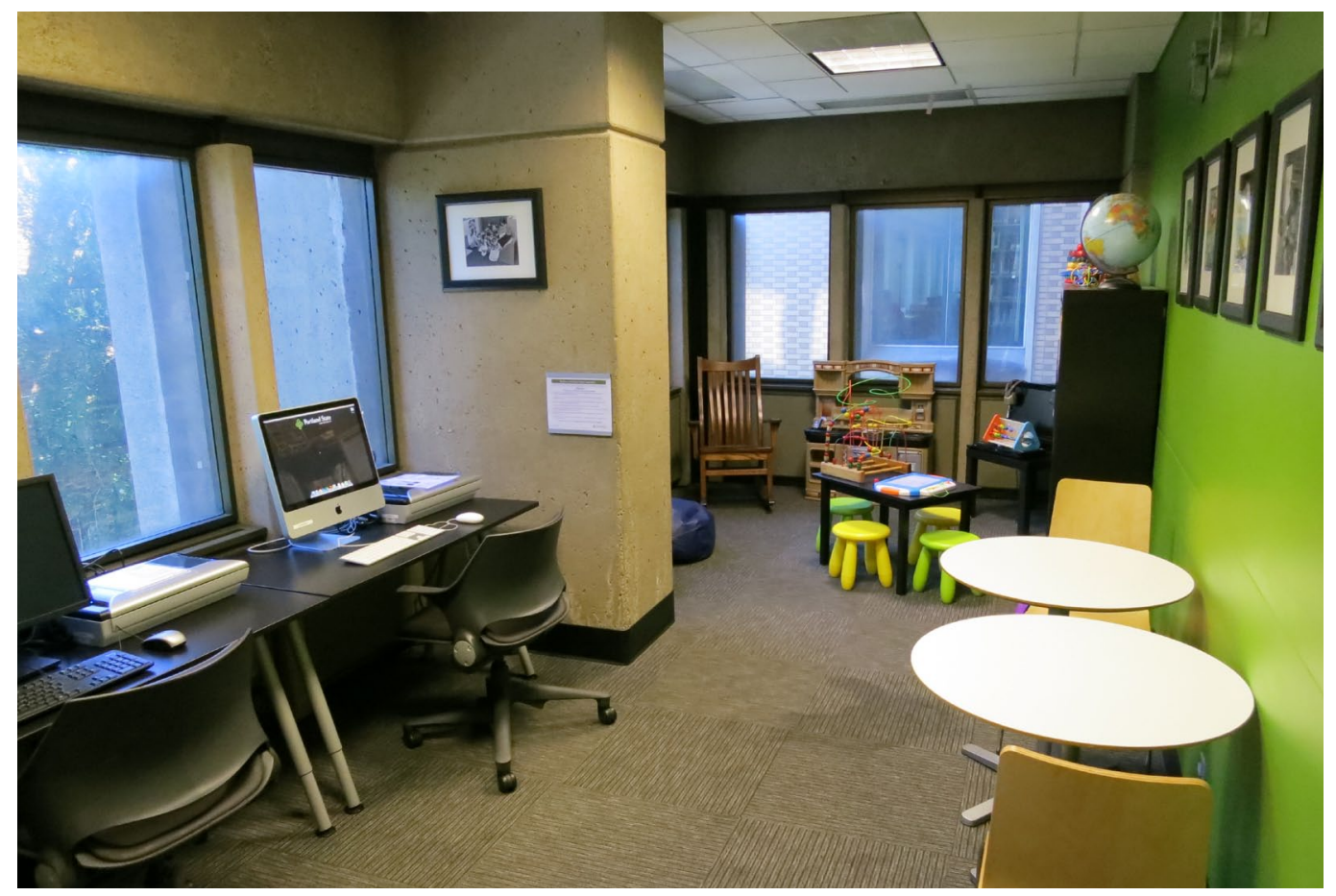

The Family Study Room at PSU Library has a PC, a Mac, two scanners, and a variety of furniture for adults and children.

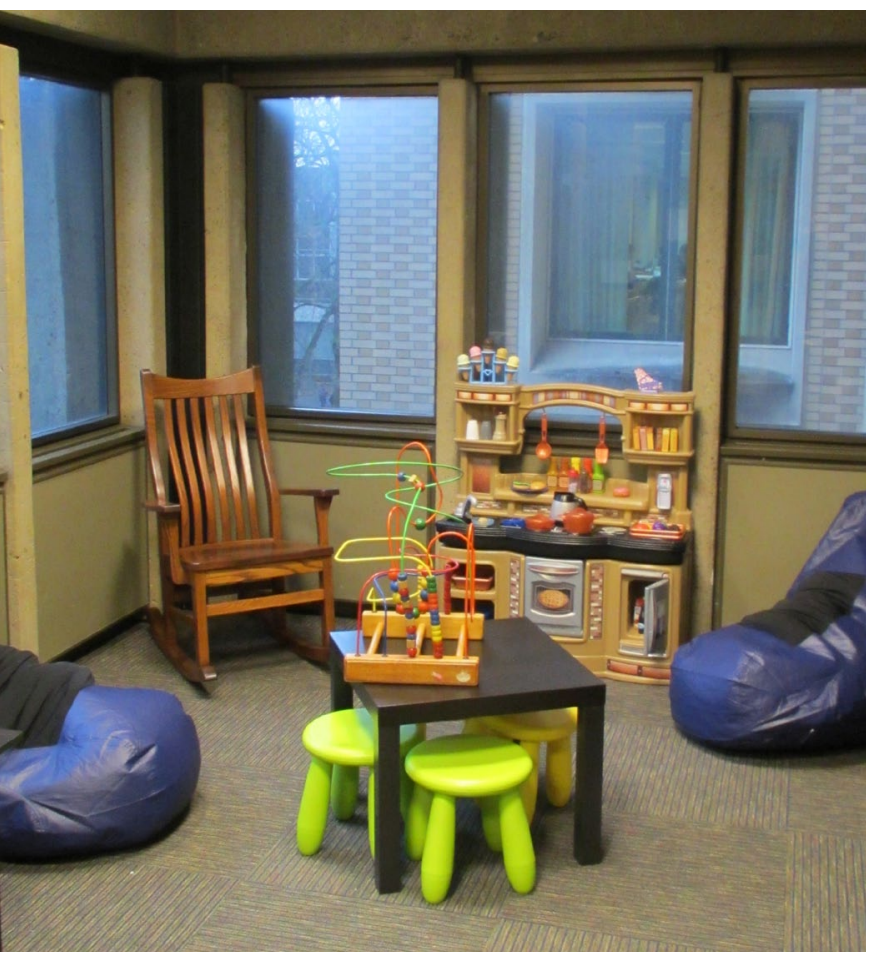

The play area includes a play kitchen, child-sized furniture, a rocking chair, and comfortable beanbags.
Child Development Center, a PSU-based preschool, with a proposal: if they provided the toys, books, and furnishings, the Library would convert an old third floor storage room into a family-friendly study space for the exclusive use of students with children. The Helen Gordon Center agreed. With assistance from the PSU Office of Information Technology, the Library added two computers and scanners for the student-parents, who gained a safe place to study without concern about wandering or bored children. The room accommodates two family groups at any given time, and students may only check out the key when their children are with them. 
In 2013, Library Development Director Jennifer Wilkerson led a refresh of the room with support from a grant from the Juan Young Trust. The room now features a brightly painted wall and new, comfortable furniture sized for adults and children; a carpeted floor; more engaging toys and books; and a television and DVD player with ALA-recommended DVDs. What might look ordinary or common in an elementary school or public library is quite vibrant and playful in an academic library.

The recent implementation of a library study room reservation system gives us data about the use of the Family Study Room. For the time period of August 2012 through November 2013, our reservations system had 5,806 unique users, 194 of whom used the Family Study Room. We had 89 users who reserved the room more than once, with 13 users reserving the room ten or more times. The Family Room saw 571 total reservations, 2 percent of all of our study rooms. While this use isn't in line with the estimated 21.5 percent of PSU students who have children, we also know that many of those students may have older children or may not bring their children to campus.

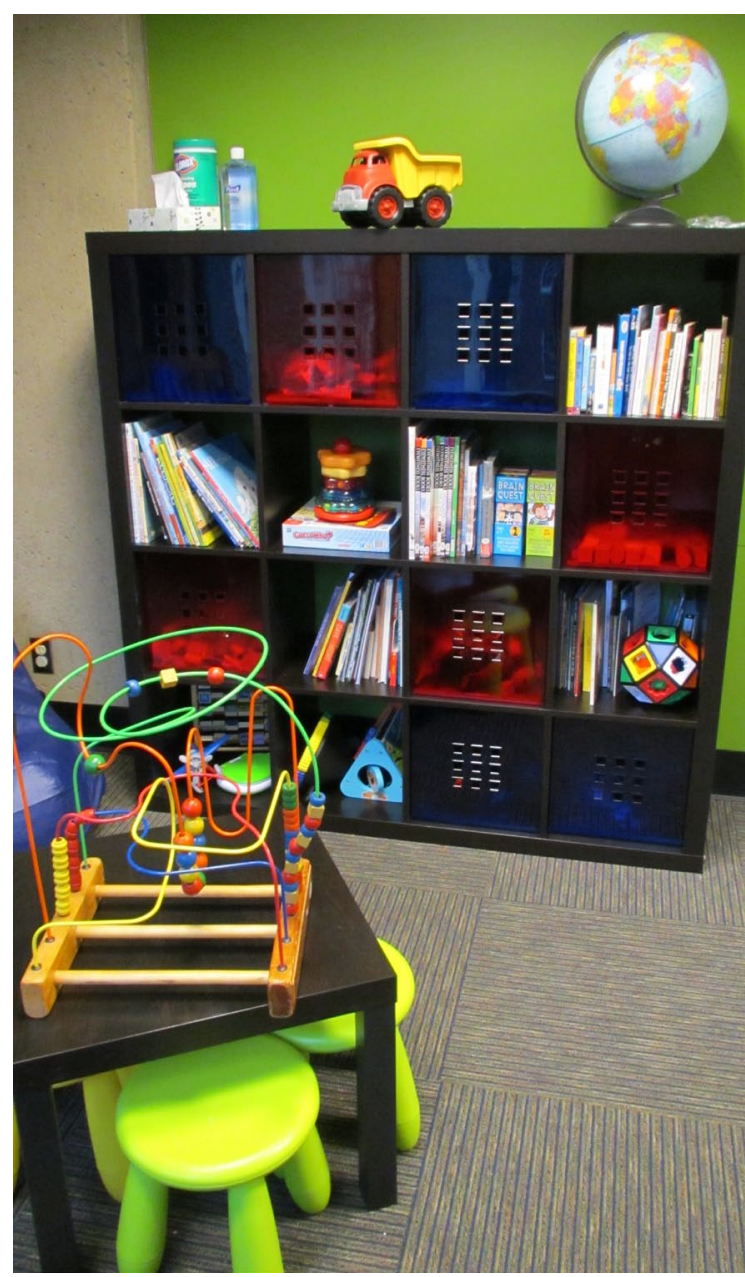

The Family Study Room offers a range of toys, books, and ALA-recommended DVDs appropriate for younger children.
And, as the Presidential Task Force noted, "Even the current familyfriendly spaces may not be well advertised" (Balzer et all 2011). It has been a challenge to promote this room to its intended audience. Some librarians make a habit of talking to students studying in the library with young children, to let them know about the Family Study Room. The PSU Resource Center for Students with Children also helps promote the room through their website, via flyers posted around the student union, and by word-of-mouth. The challenge may be, in part, because our students do not expect the library to have a space dedicated to students with children. In fact, while researching for this article, I was able to identify only one other similar study space in an academic library, the Family Room at Collins-Callaway Library and Learning Resources Center at Paine College in Augusta, Georgia. Collins-Callaway Library was similarly motivated by a "growing population (of) students with families, including small children," and they report increased traffic from this population with the establishment of the new space (McCoy, 2013). 
Looking ahead, we hope to see increased use of the room through additional, targeted promotion as well as a survey of the students who have used the room. We want to know how the Family Study Room meets their needs and how it could be better.

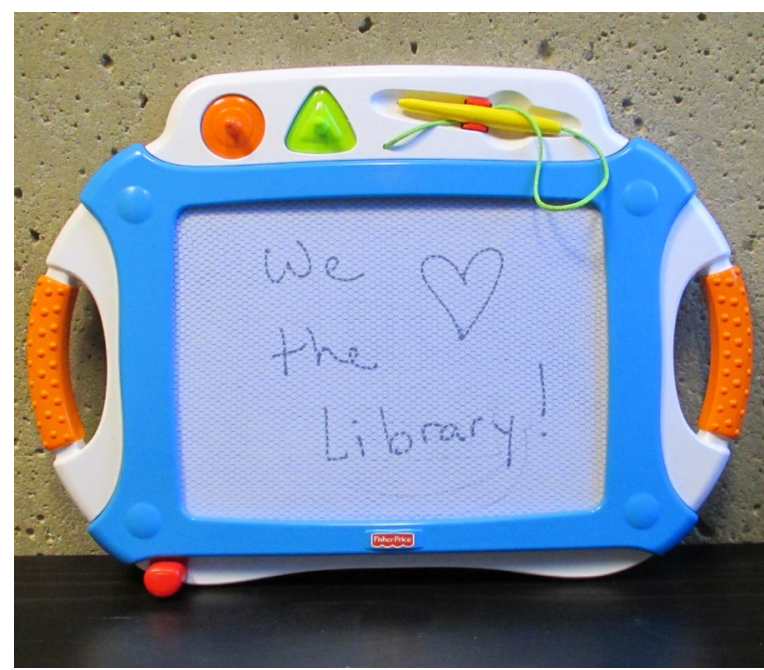

The Family Study Room at PSU Library has a small, but loyal following.
According to Brown and Nichols (2012), college students with children face additional barriers to completion, including the difficulty of juggling various responsibilities to work, family, and school; they are also less likely to graduate than their classmates without children and are often unaware of campus resources available to them. Given that this is a particularly vulnerable population, PSU Library feels that the Family Study Room is a good investment in our students and a good use of space in the library building. The presence of the room generates a large amount of goodwill, even amongst students who do not have young children. And we hope that student-parents enjoy the room not simply to keep their children busy, but also to expose them to educational toys and books and the advantages of a college education.

\section{Acknowledgements}

The author wishes to thank PSU Library Manager of Library Technologies Nathan Mealey for collecting and organizing the data used in this article.

\section{References}

Balzer, J., Hitz, R., Baker, A., D’Urso, B., Goll, J., Gregory, M., ... Stoering, J. (2011). Presidential task force on child development and family support. Retrieved from Portland State University, Resource Center for Students with Children website: http://tinyurl.com/jw8requ

Brown, V., \& Nichols, T. R. (2012). Pregnant and parenting students on campus: Policy and program implications for a growing population. Educational Policy, 27(3), 499-530. http://dx.doi.org/10.1177/0895904812453995

McCoy, R. (2013). Georgia library spotlight-The family room, Collins-Callaway Library \& Learning Resources Center, Paine College. Georgia Library Quarterly 50 (4), Article 5. http://digitalcommons.kennesaw.edu/glq/vol50/iss4/5

Portland State University. (2012). Student profile: Total enrollment. Retrieved from Portland State University, Office of Institutional Research and Planning website: http://www.oirp.pdx.edu/source/port1213/all_all.htm 